\title{
Effect of abamectin on development of chick embryo
}

\author{
Kainat Sardar, Khadija Zafar, Uzaira Khalid, Nadia Sattar, Zeerak \\ Mustabshira and Shazia Perveen* \\ Affiliation; Department of Zoology, The Women University matital campus Multan-Pakistan \\ *Corresponding author's email: drshazia.zool@wum.edu.pk \\ Citation \\ Kainat Sardar, Khadija Zafar, Uzaira Khalid, Nadia Sattar, Zeerak Mustabshira and Shazia Perveen. Effect of \\ abamectin on development of chick embryo. Pure and Applied Biology. Vol. 9, Issue 2, pp1266-1278. \\ http://dx.doi.org/10.19045/bspab.2020.90132
}

\begin{tabular}{llll}
\hline \hline Received: 28/10/2019 & Revised: 02/01/2020 & Accepted: 23/01/2020 & Online First: 13/02/2020 \\
\hline \hline
\end{tabular}

\section{Abstract}

Abamectin is widely used as an insecticide and pesticide on crops. Despite of its beneficial uses it also induces some adverse effects like it causes infertility in farmers who frequently encounter abamectin. It is broadly used but little is known about its effects on avian. To check its teratogenic effects on developing chick embryo abamectin is injected into fertilized chick embryos. In chick embryo, gross anomalies and morphological changes are observed. The results of this experiment indicated that low dose of abamectin has adverse effects than that of high dose, as low dose of abamectin reduces the growth rate of developing chick embryo and delayed hatching. Moreover, hatched chicks are physically weak.

Keywords: Acetone; Chick Embryo; Growth; Pesticide; Teratogen

\section{Introduction}

Abamectin (ABM) is a macrocyclic lactone product derived from the soil microorganism Streptomyces avermitilis. ABM is used as an insecticide and acaricide in many parts of the world, and acts as an agonist of $\gamma$ aminobutyric acid [1, 2]. Abamectin is a derivative of avermectin. It acts on gammaaminobutyric acid (GABA) receptors in both vertebrates and invertebrates [3]. Abamectin is highly lipophilic due to which it adsorbs strongly to the soil surfaces and undergoes rapid photolysis. This property of abamectin limits its mobility and transport from treated agricultural fields to surface water as well as into groundwater [4]. ABM was examined against the newly hatched larvae (neonate) and 25 days old larvae of Red Palm Weeli, Rhynchophorus ferruginous (Olivier) results showed that high concentration of abamectin induced mortality in new larvae but low mortality rate in older larvae. Abamectin also affect the hatching of eggs and development of cocoon. Consequently, the life cycle of insect is disrupted and likewise the rest of the developmental stages including egg, larva and pupa [5]. Abamectin is one of the most commonly used pesticides throughout the world. Its effect on aquatic animals had been observed, abamectin induce toxicity in $D$. rerio. Abamectin and difenoconazole pesticides cause greater toxicity in the fish $\mathrm{D}$. rerio when they act synergistically [6]. Abamectin has characteristic of crossing the blood brain barrier in fish to cause toxicity, unlike in mammals. In both vertebrates and invertebrates, abamectin act on the receptors of gamma amino butyric acid (GABA), it 
also acts on glutamatergic receptors present in the chloride channels of invertebrates [3]. The exposure to abamectin causes an increase in chloride ions which will hyperpolarize the nerve and muscle cells thus ultimately interfere with neuromuscular transmission that can lead to death [7]. The static exposure of zebrafish embryos to abamectin from 5-25 hpf suggested it inhibits the neurotransmission by the reversibly activating ligand- gated but abamectin did not affect the outgrowth of neurite from spinal motor-neurons thus making the embryos vulnerable to hypoactivity [8]. Mateus investigated that the cytotoxic effects of lower concentration of abamectin on Lithobates catesbeianus tadpoles. It ascertains the hypothesis that abamectin caused cytotoxic effects on L. catesbeianus tadpoles, even though the exposure lasted short and the concentrations were low. It revealed the likelihood for variations in the nucleus of erythrocytes circulating in amphibians [9].

In mammals, abamectin administration to male rats causes decreased sperm count, motility and increased damage in seminiferous tubule. There is also an elevated level of 4-hydroxy-2-nonenal (4-HNE)modified proteins and poly (ADP-ribose) (PAR) expression, as markers for oxidative stress and poly (ADP-ribose) polymerase (PARP) activation, observed in rat testes exposed to abamectin [10]. In birds, the cytotoxic effects caused by low abamectin concentrations on the erythrocytes of female Japanese quails were investigated $[11,12]$. It revealed distinct physical abnormalities in those birds exposed to higher abamectin levels such as nuclear shapes (asymmetric constriction nuclei in erythrocytes, notched nuclei, indented and moved nucleus) [11]. Cultured primary King pigeon brain neurons were exposed to avermectin. The results showed that AVM inhibited neuronal mitochondria activity, decreased the $\Delta \psi \mathrm{m}$, and increased the activities of Caspases $3 \&$ 9. They indicated that AVM could induce the apoptosis of the cultured brain neurons through mitochondrial injury [13]. As little is known about abamectin effect on birds therefore the present study is based on abamectin effect on chick embryos. As it acts through GABA receptors, so it can be concluded that it might affect embryo development; hence teratogenicity in chick embryos is also under consideration.

\section{Materials and methods}

\section{Test compound}

Abamectin (95\% pure) is supplied by National Engineering Services Pakistan Pvt. Stock solution is made with $0.01 \mathrm{~g}$ abamectin dissolved in solvent acetone $(50 \mathrm{ml})$ and distilled water $(50 \mathrm{ml})$, working solutions was made from stock solution, 5 different doses of abamectin $0.5 \mu \mathrm{g}, 1.25 \mu \mathrm{g}, 2.5 \mu \mathrm{g}$, $5 \mu \mathrm{g}$ and $10 \mu \mathrm{g}$ were given to embryos.

\section{Experiment model}

Fertilized eggs of vingeo layer chicken were purchased from Conimpex Hatchery and Breeding Farm. Total eggs were 60, all the eggs were healthy and pathogens free. Eggs were weighed that ranges from $51-62 \mathrm{~g}$. Then eggs were cleaned with $70 \%$ ethanol for aseptic condition and labeled them. Place eggs in incubator and maintain the temperature of incubator at $37.5^{\circ} \mathrm{C}$. Eggs were rotated regularly.

\section{Dose administration}

Eggs were divided into 6 groups; each group consist of 10 eggs $(n=10)$. One is control group and remaining five are experimental groups. Candled the eggs to mark the yolk sac and a hole is made in the shell at $45^{\circ}$ from air sac cavity. The experimental groups were injected with different concentrations of abamectin solution (Graph 1). On the third day of incubation, doses of abamectin $0.5 \mu \mathrm{g}$, $1.25 \mu \mathrm{g}, 2.5 \mu \mathrm{g}, 5 \mu \mathrm{g}$ and $10 \mu \mathrm{g}$ were injected to all the experimental groups $\mathrm{A}, \mathrm{B}, \mathrm{C}, \mathrm{D}, \mathrm{E}$ respectively. Dose was given to all experimental groups by inserting syringe 
through the hole after that hole was sealed with paraffin. The eggs were placed back in incubator. Eggs were rotated twice per day.

\section{Observation of embryos}

Eggs were opened on the 8th day of drug administration. Two eggs were sacrificed from each group while placing them in Petri dishes. Wash the embryos with tap water and development was observed. The eye size of embryo and total length of embryo were measured with the help of digital Vernier caliper enlisted in (Table 1). The remaining eggs were opened on 23rd day of incubation, growth rate of all chick embryos varies with abamectin dose shown in (Graph 2).

\section{Results}

According to Hamilton stages on the 8th day certain characteristics like beak formation, limbs formation, blood vessels formation, development of feather germs was observed by comparing them with control group embryos. Embryo of control group when opened at $8^{\text {th }}$ day showed normal growth i.e development of limbs, beak, and feather germs, heart and blood vessels were also present as displayed in (Fig. 1 \& 2) and there is no significant effect of abamectin on the weight of embryo at $8^{\text {th }}$ day (Graph 3) but low dose of abamectin affected the total length (size) of chick embryos as displayed in (Graph 4). The ANOVA analysis between the dose and eye size of embryos on day 8 proved that reducing the amount of abamectin shortened the eye size (Graph 5). The eggs of group A injected with $10 \mathrm{mg} / \mathrm{L}$ dose of abamectin which showed negligible effect on chick development as showed in (Fig. 3). Little adverse effects were observed in group B which were injected with $5 \mathrm{mg} / \mathrm{L}$ dose of abamectin. Blood vessels were damaged, heart was ruptured, but limb and beak formation were normal (Fig. 4). Embryos of Group C treated with $2.5 \mathrm{mg} / \mathrm{L}$ dose of abamectin indicated poor feather germ layer, damage heart, blood vessels, embryo length were also affected (Fig. 5). In group D 1.25 $\mathrm{mg} / \mathrm{L}$ dose was injected that showed poor limbs formation, poor development of blood vessels, heart, feather germ layer and small size of embryo. With decreasing drug dose, effects are more prominent as seen in Group E (Fig. 6).

\section{2nd day findings}

Chicks from control group comes out normally on 22nd day of incubation appeared physically active and healthy (Fig. 7) their observations are given in (Table 2), few chicks from experimental group also hatched normally but they were physically weak with poor walking (Fig. 8). At the end of experiment on $23^{\text {rd }}$ day, to some chicks help is provided for hatching (Fig. 9) while in few eggs where there is no sign of hatching (under development) those were opened and their data is given in (Table $3 \& 4$ ) yet no significant change had seen in weight of experimental group chicks when compared with control (Graph 6) while the size and eye size of group D chicks was smaller than that of normal range as shown in (Graph $7 \& 8$ ). Embryos of group A injected with $10 \mathrm{mg}$ dose of abamectin show similarities with normal chicks of control groups, many of them hatched on normal time and few eggs were assisted in hatching, yet their development is near to complete with proper formation of all organs and feathers also covered the body but in some chicks' yolk is still present outside the body (Fig. 10). Embryos injected with $5 \mathrm{mg}$ dose of abamectin show slow growth, poor yolk sac retraction (Fig. 11) although the chick size is normal. In group $\mathrm{C}$ of experimental groups that were injected with $2.5 \mathrm{mg} / \mathrm{l}$ of abamectin chicks shows delaying in hatching, failure of yolk-sac retraction and have reduce body weight, embryo length smaller eyes size (Fig. 12). Embryos injected with slightly increase in dose to $1.25 \mathrm{~m} / \mathrm{L}$ showed ectopia viscera, which only small eyes and heart developed, and took long time for hatching (Fig. 13). While in embryos given Low dose of 
abamectin $0.5 \mathrm{mg}$ show in many eggs retardation in development occurred in development and their growth ceased at initial stage of development only few blood vessels were formed, heart developmental arrest occurred (Fig. 14 \& 15).

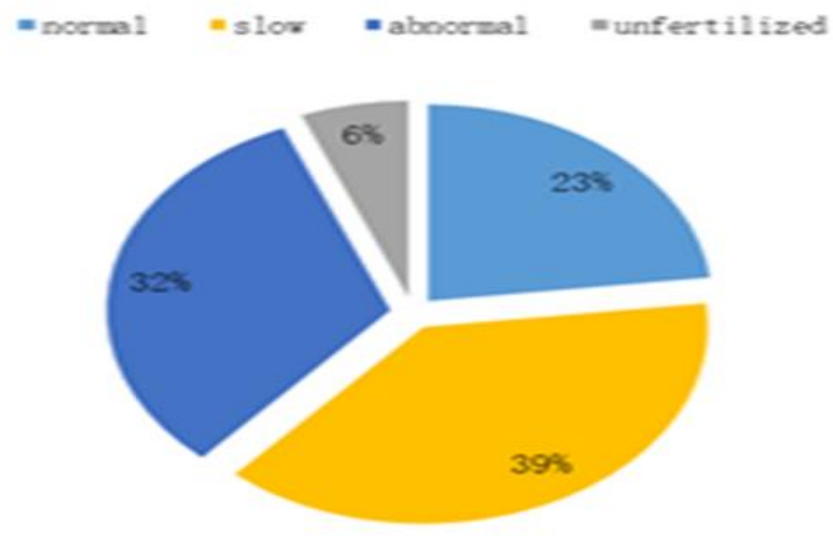

Graph 1. Percentage of different type of Growth in all chick embryos

Table 1. Data about Eggs opened on $8^{\text {th }}$ day after drug administration

\begin{tabular}{|c|c|c|c|c|c|}
\hline Egg no & Group & $\begin{array}{c}\text { Dose mg/ } \\
\mathbf{~ K g}\end{array}$ & $\begin{array}{c}\text { Embryo's } \\
\text { weight }\end{array}$ & $\begin{array}{c}\text { Embryo size in } \\
\text { mm }\end{array}$ & Eye size in mm \\
\hline 2 & Experimental A & $10 \mathrm{mg} \mathrm{Kg}$ & $53.60 \mathrm{~g}$ & 34.41 & 7.47 \\
\hline 11 & Experimental B & $5 \mathrm{mg} / \mathrm{Kg}$ & $57.54 \mathrm{~g}$ & 30.49 & 9.43 \\
\hline 12 & Experimental B & $5 \mathrm{mg} / \mathrm{Kg}$ & $58.68 \mathrm{~g}$ & 31.94 & 8.78 \\
\hline 21 & Experimental C & $2.5 \mathrm{mg} / \mathrm{Kg}$ & $55.71 \mathrm{~g}$ & 29.73 & 7.22 \\
\hline 22 & Experimental C & $2.5 \mathrm{mg} / \mathrm{Kg}$ & $54.66 \mathrm{~g}$ & 27.47 & 6.4 \\
\hline 31 & Experimental D & $1.25 \mathrm{mg} / \mathrm{Kg}$ & $62.85 \mathrm{~g}$ & 22.41 & 5.42 \\
\hline 32 & Experimental D & $1.25 \mathrm{mg} / \mathrm{Kg}$ & $60.93 \mathrm{~g}$ & 24.13 & 4.86 \\
\hline 51 & Control & $\mathrm{Nil}$ & $53.63 \mathrm{~g}$ & 40.69 & 7.25 \\
\hline 52 & Control & $\mathrm{Nil}$ & $53.81 \mathrm{~g}$ & 38.27 & 5.54 \\
\hline
\end{tabular}

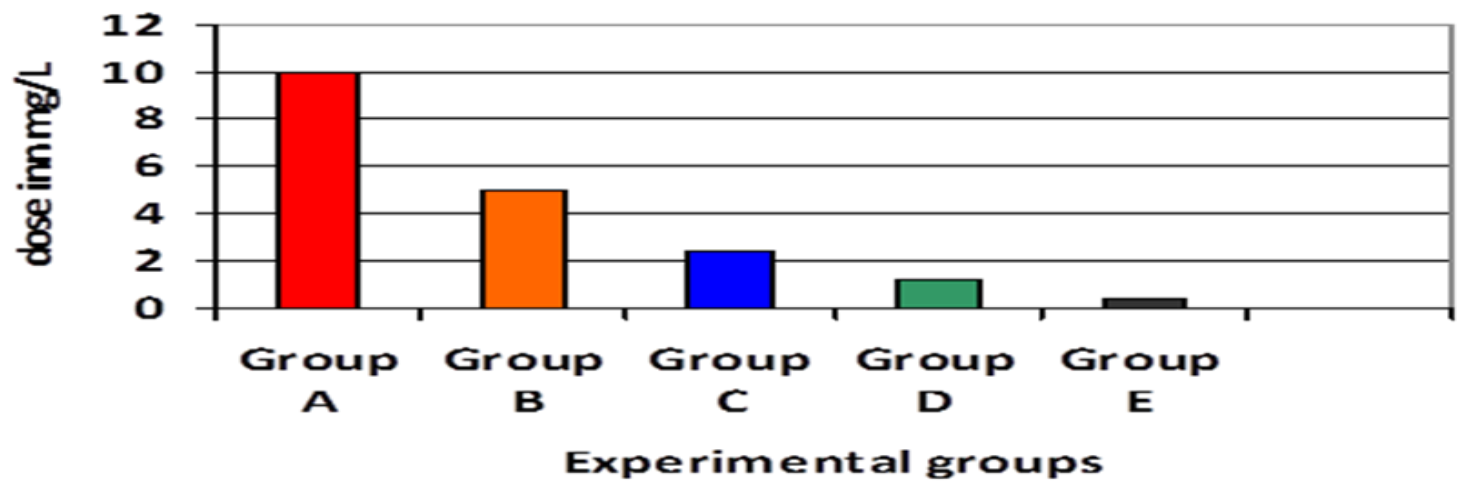

Graph 2. Dose quantity given to specific experimental group 


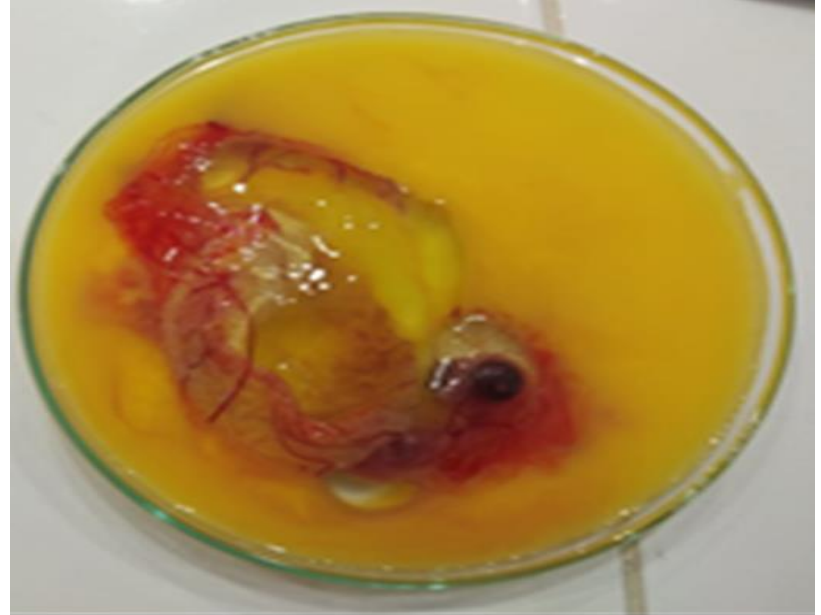

Figure 1. Control group embryos opened on $8^{\text {th }}$ day of drug Administration show proper allantois formation

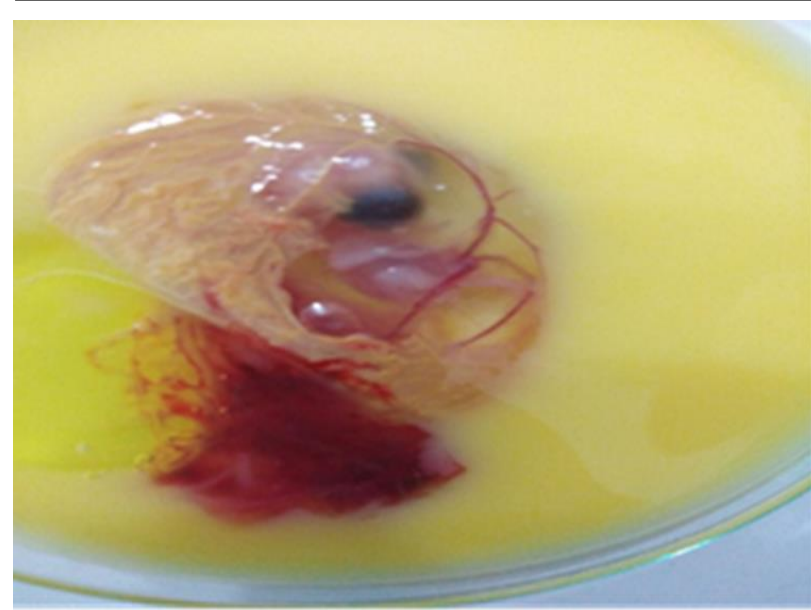

Figure 3. In Control group embryos opened on $8^{\text {th }}$ occurred with Proper Feather germ layer formation

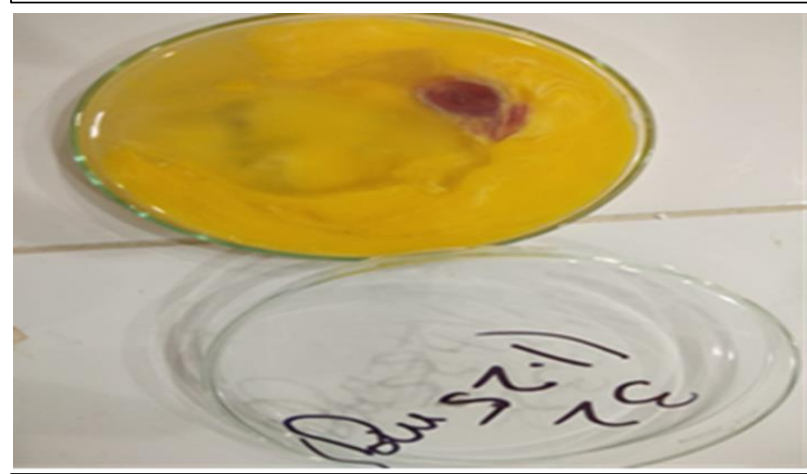

Figure 5. Growth arrest occurs in experimental group $\mathrm{C}$

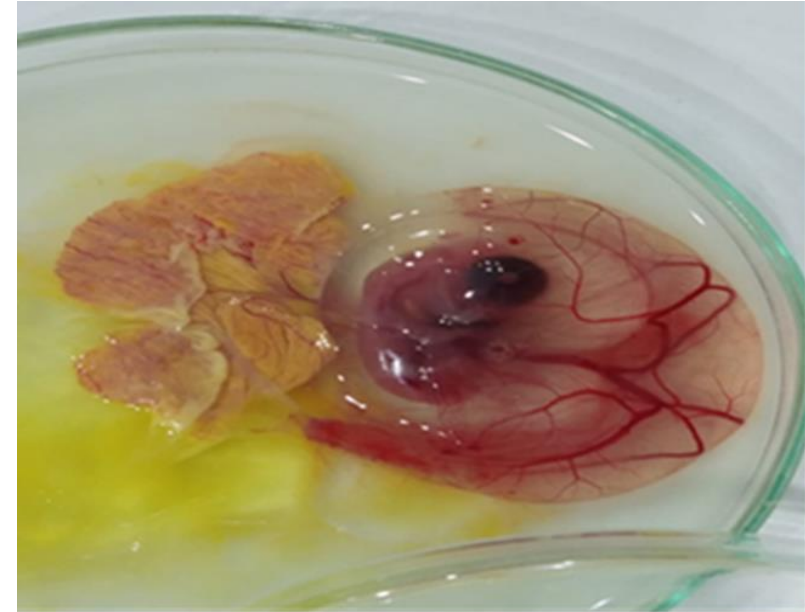

Figure 2. Control group Embryo after washing

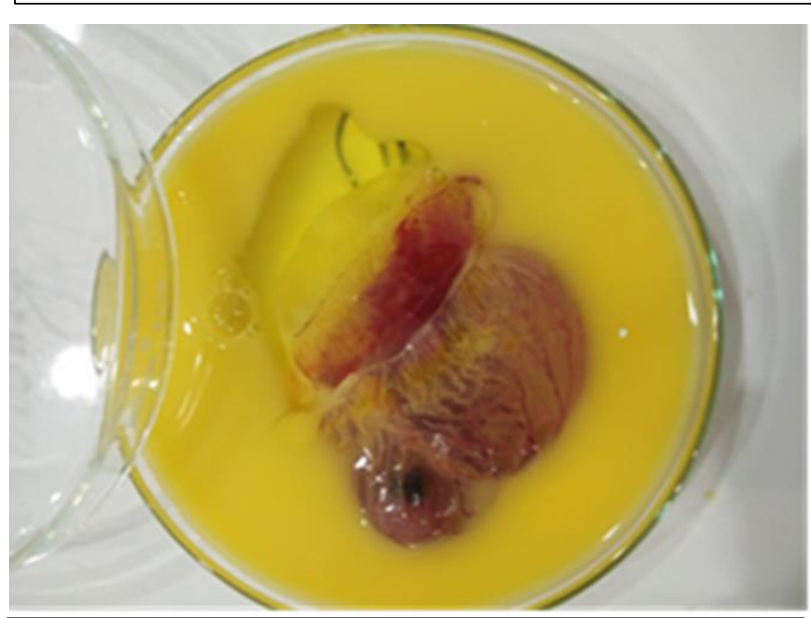

Figure 4. Embryo of experimental group B showing slow growth

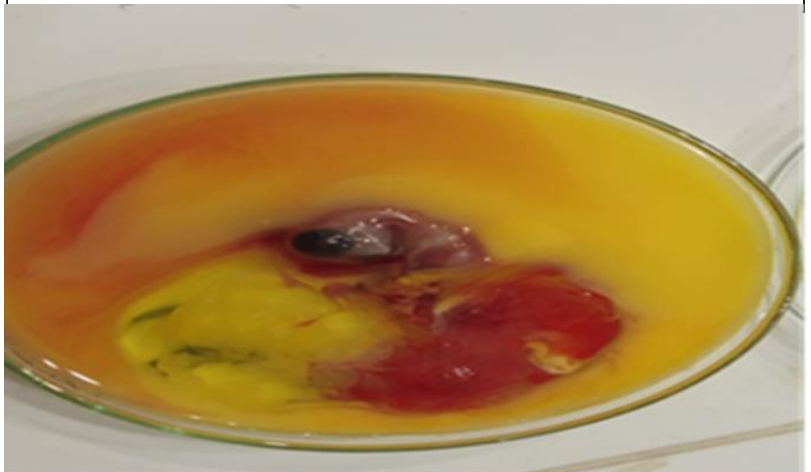

Figure 6. Damaged blood vessels seen in Experimental group embryo 


\section{Figure 7. Normal hatching seen in control group}

Table 2. General information about all the eggs, body weight and eye size of chicks hatched normally

\begin{tabular}{|c|c|c|c|c|c|c|}
\hline Group & $\begin{array}{c}\text { Contro } \\
\mathbf{l}\end{array}$ & $\begin{array}{c}\text { Experimental } \\
\text { A }\end{array}$ & $\begin{array}{c}\text { Experimental } \\
\text { B }\end{array}$ & $\begin{array}{c}\text { Experimental } \\
\text { C }\end{array}$ & $\begin{array}{c}\text { Experimental } \\
\text { D }\end{array}$ & $\begin{array}{c}\text { Experimental } \\
\text { E }\end{array}$ \\
\hline $\begin{array}{c}\text { No. Of } \\
\text { hatched eggs }\end{array}$ & 5 & 3 & 1 & 2 & 1 & 0 \\
\hline $\begin{array}{c}\text { Dose mg/ } \\
\text { Kg }\end{array}$ & 0 & 10 & 5 & 2.5 & 1.25 & 0.5 \\
\hline $\begin{array}{c}\text { Time of } \\
\text { incubation }\end{array}$ & 22 days & 22 days & 22 days & 22 days & 22 days & 22 days \\
\hline $\begin{array}{c}\text { Body weight } \\
\text { range }\end{array}$ & $53-57 \mathrm{~g}$ & $52-54 \mathrm{~g}$ & $57-59 \mathrm{~g}$ & $54-56 \mathrm{~g}$ & $60-63 \mathrm{~g}$ & $57-59 \mathrm{~g}$ \\
\hline $\begin{array}{c}\text { Body size } \\
\text { mean value }\end{array}$ & $\begin{array}{c}168 \\
\mathrm{~mm}\end{array}$ & $165.2 \mathrm{~mm}$ & $166 \mathrm{~mm}$ & $148 \mathrm{~mm}$ & $142 \mathrm{~mm}$ & $140 \mathrm{~mm}$ \\
\hline $\begin{array}{c}\text { Eye size } \\
\text { mean value }\end{array}$ & $\begin{array}{c}10.2 \\
\mathrm{~mm}\end{array}$ & $8.4 \mathrm{~mm}$ & $6.8 \mathrm{~mm}$ & $5.9 \mathrm{~mm}$ & $6 \mathrm{~mm}$ & $5.7 \mathrm{~mm}$ \\
\hline
\end{tabular}

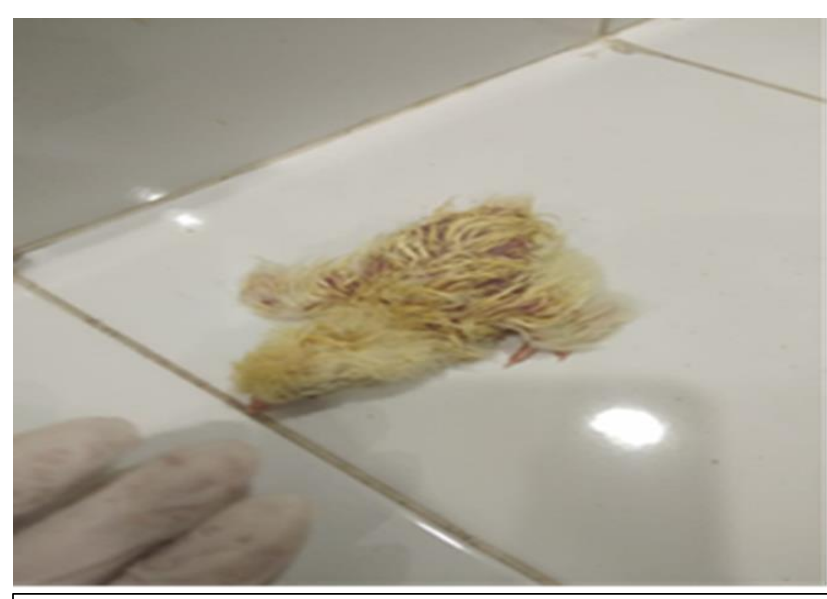

Figure 8. Physically weak chick of experimental group

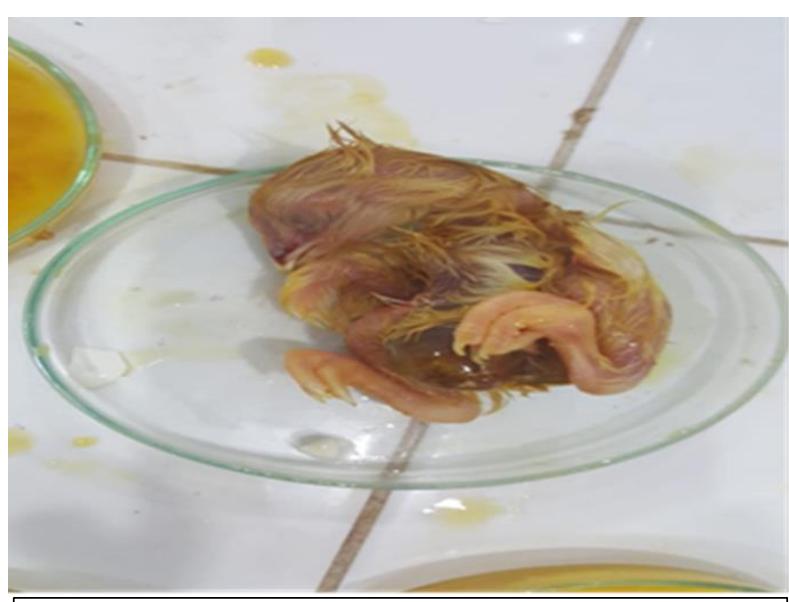

Figure 9. Assisted hatching was provided to un-hatched eggs of Experimental group 
Table 3. Data of eggs in which hatching was assisted

\begin{tabular}{|c|c|c|c|c|c|c|}
\hline Group & $\begin{array}{c}\text { Contr } \\
\text { ol }\end{array}$ & $\begin{array}{c}\text { Experimental } \\
\text { A }\end{array}$ & $\begin{array}{c}\text { Experimental } \\
\text { B }\end{array}$ & $\begin{array}{c}\text { Experimental } \\
\text { C }\end{array}$ & $\begin{array}{c}\text { Experimental } \\
\text { D }\end{array}$ & $\begin{array}{c}\text { Experimental } \\
\text { E }\end{array}$ \\
\hline $\begin{array}{c}\text { No. Of } \\
\text { hatched eggs }\end{array}$ & 1 & 3 & 4 & 3 & 2 & 1 \\
\hline $\begin{array}{c}\text { Dose } \mathrm{mg} / \\
\mathrm{Kg}\end{array}$ & 0 & 10 & 5 & 2.5 & 1.25 & 0.5 \\
\hline $\begin{array}{c}\text { Time of } \\
\text { incubation }\end{array}$ & $\begin{array}{c}23 \\
\text { days }\end{array}$ & 23 days & 23 days & 23 days & 23 days & 23 days \\
\hline Body weight & $\begin{array}{c}53-57 \\
\mathrm{~g}\end{array}$ & $52-54 \mathrm{~g}$ & $57-59 \mathrm{~g}$ & $52-56 \mathrm{~g}$ & $60-63 \mathrm{~g}$ & $57-59 \mathrm{~g}$ \\
\hline $\begin{array}{c}\text { Body size } \\
\text { range }\end{array}$ & $\begin{array}{c}166- \\
170 \mathrm{~m} \\
\mathrm{~m}\end{array}$ & $163-166.4 \mathrm{~mm}$ & $164-168 \mathrm{~mm}$ & $146-150 \mathrm{~mm}$ & $140-144 \mathrm{~mm}$ & 0 \\
\hline $\begin{array}{c}\text { Eye size } \\
\text { range }\end{array}$ & $\begin{array}{c}9-11 \\
\mathrm{~mm}\end{array}$ & $7.4-8.8 \mathrm{~mm}$ & $7.0-6.3 \mathrm{~mm}$ & $5-5.9 \mathrm{~mm}$ & $5-6 \mathrm{~mm}$ & 0 \\
\hline
\end{tabular}

Table 4. Eggs opened on 23rd day after drug administration

\begin{tabular}{|c|c|c|c|c|c|}
\hline Chicks & Group & $\begin{array}{c}\text { Given dose in } \\
\mathbf{m g} / \mathbf{K g}\end{array}$ & $\begin{array}{c}\text { Weight in } \\
\text { grams }\end{array}$ & $\begin{array}{c}\text { Embryo's length in } \\
\mathbf{m m}\end{array}$ & $\begin{array}{c}\text { Eye size in } \\
\text { mm }\end{array}$ \\
\hline 16 & Experimental A & $10 \mathrm{mg} / \mathrm{Kg}$ & $52.44 \mathrm{~g}$ & 163.68 & 8.30 \\
\hline 25 & Experimental A & $10 \mathrm{mg} / \mathrm{Kg}$ & $54.85 \mathrm{~g}$ & 164.98 & 8.48 \\
\hline 27 & Experimental B & $5 \mathrm{mg} / \mathrm{Kg}$ & $58.65 \mathrm{~g}$ & 162.89 & 6.98 \\
\hline 39 & Experimental B & $5 \mathrm{mg} / \mathrm{Kg}$ & $57.58 \mathrm{~g}$ & 166.70 & 5.94 \\
\hline 44 & Experimental C & $2.5 \mathrm{mg} / \mathrm{Kg}$ & $53.30 \mathrm{~g}$ & 145.55 & 5.85 \\
\hline 47 & Experimental D & $1.25 \mathrm{mg} / \mathrm{Kg}$ & $61.66 \mathrm{~g}$ & 141.50 & 4.74 \\
\hline 48 & Experimental D & $1.25 \mathrm{mg} / \mathrm{Kg}$ & $62.59 \mathrm{~g}$ & 143.78 & 5.47 \\
\hline
\end{tabular}

\section{Interval Plot of Body Weight (g) vs Abamectin ( $\mathrm{mg} / \mathrm{kg}$ ) $95 \% \mathrm{Cl}$ for the Mean}

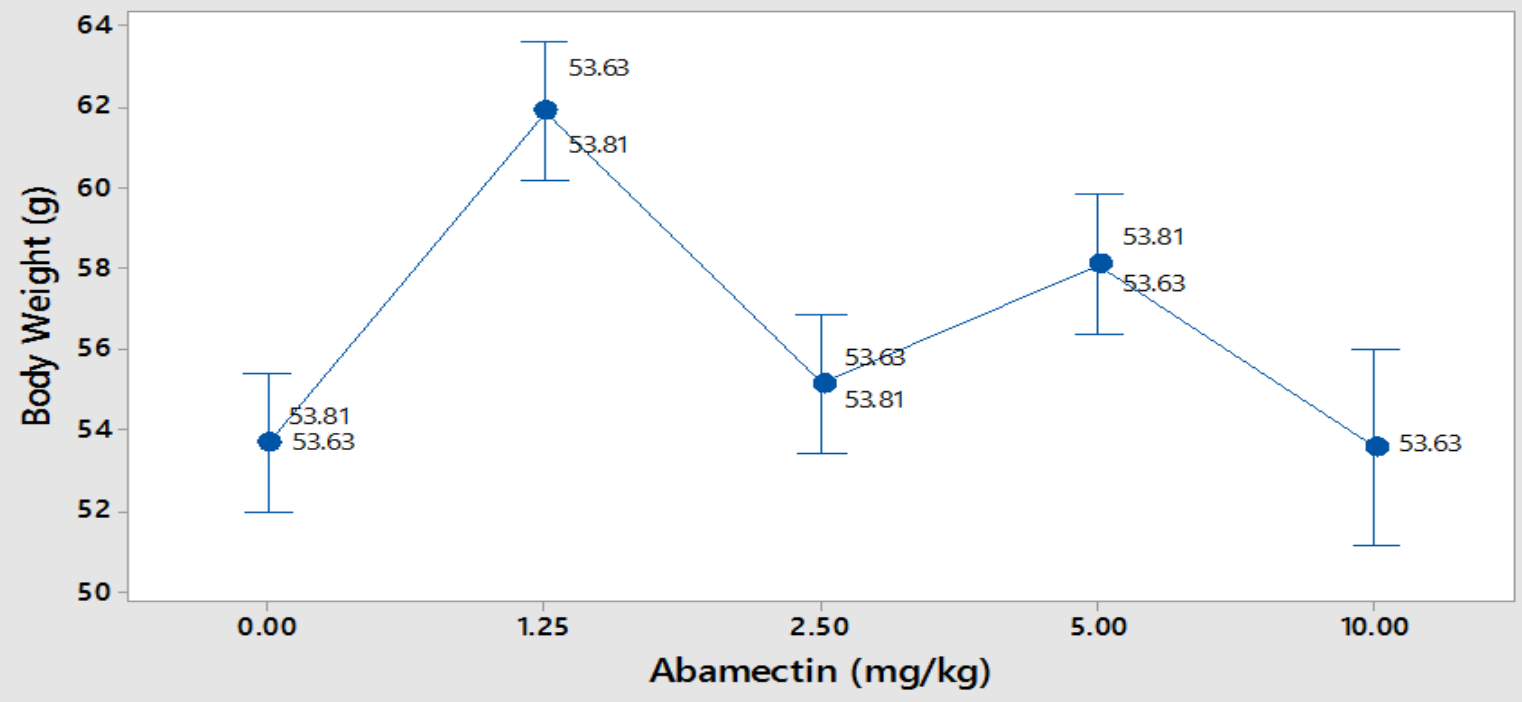

The pooled standard deviation is used to calculate the intervals.

Graph 3. One-way ANOVA analysis between dosage and body weight of Chicks on $8^{\text {th }}$ day 


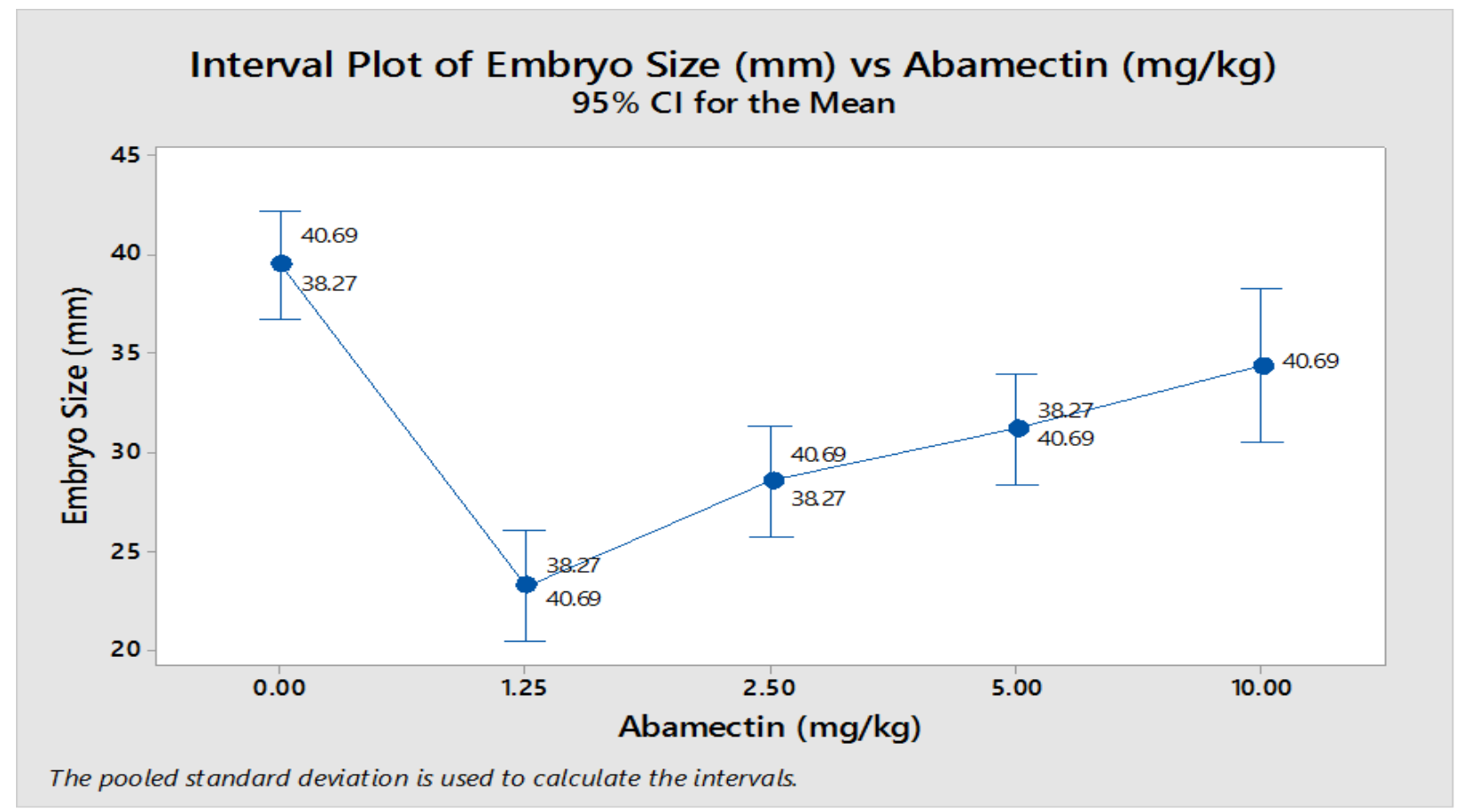

Graph 4. One-way ANOVA analysis between dosage and embryo size of chicks on $8^{\text {th }}$ day

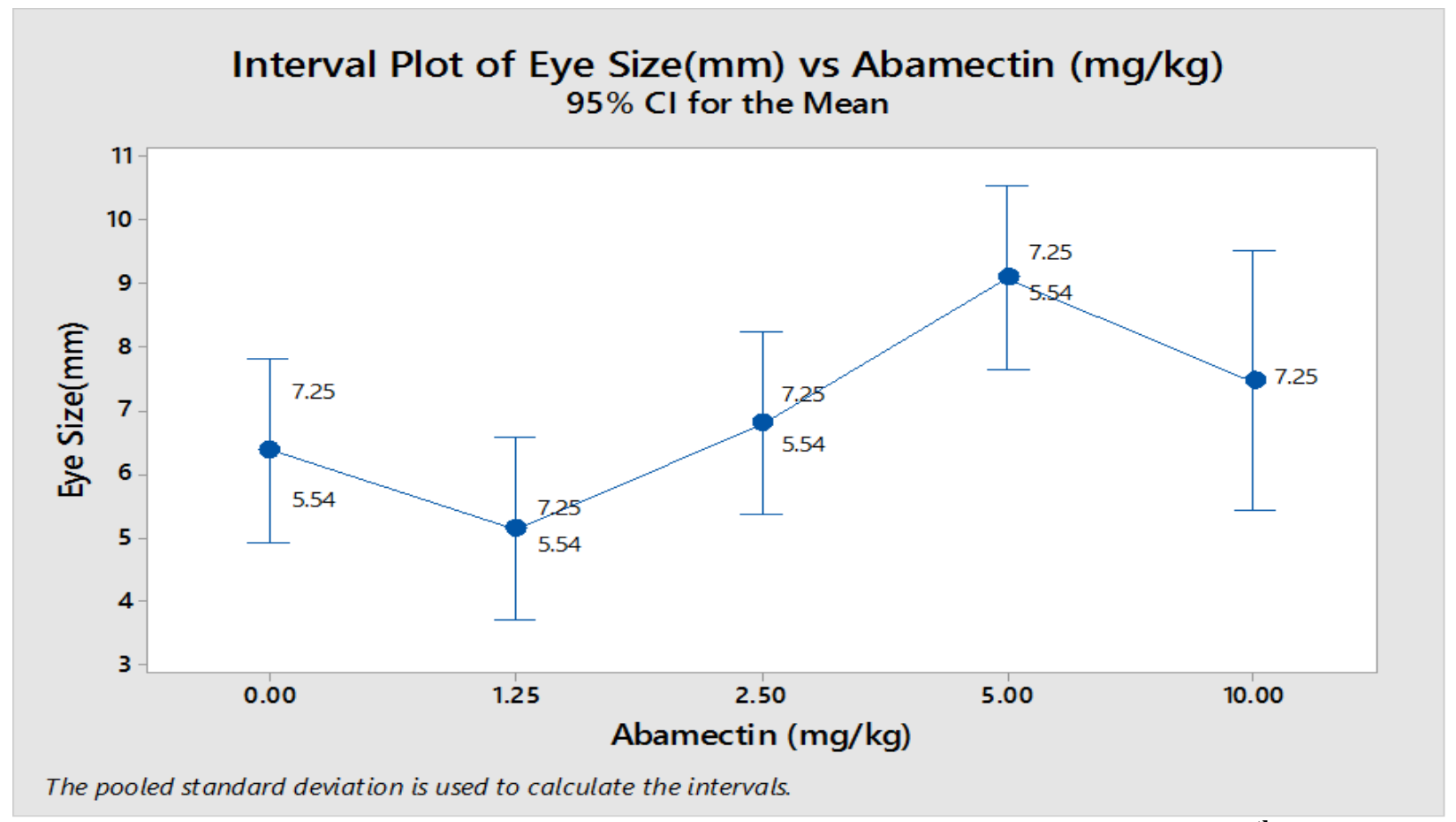

Graph 5. One-way ANOVA analysis between dosage and eye size of chicks on $8^{\text {th }}$ day 


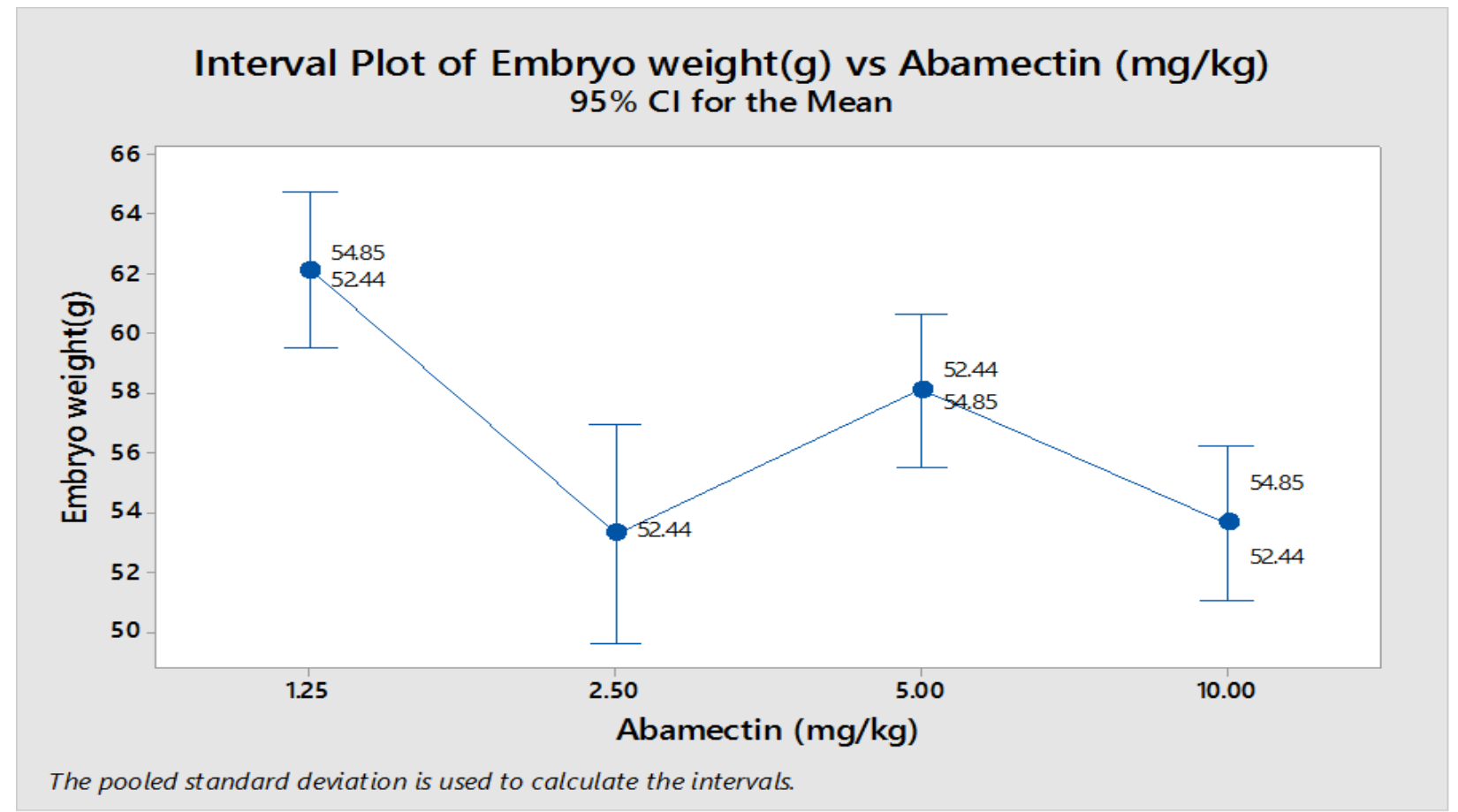

Graph 6. One-way ANOVA analysis between dosage and embryo weight of chicks on $23^{\text {rd }}$ day

Interval Plot of Embryo length ( $\mathrm{mm})$ vs Abamectin $(\mathrm{mg} / \mathrm{kg})$ $95 \% \mathrm{Cl}$ for the Mean

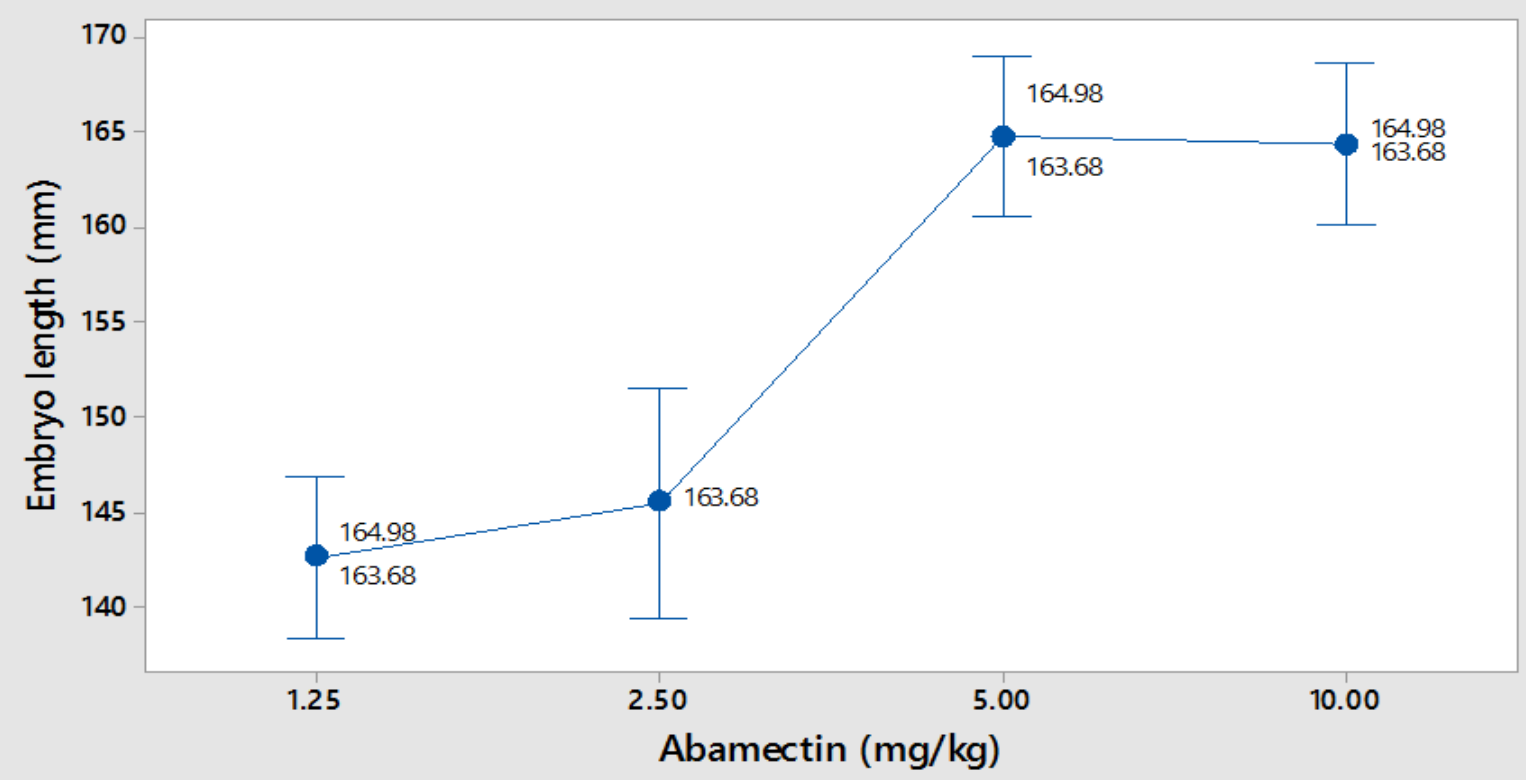

The pooled standard deviation is used to calculate the intervals.

Graph 7. One-way ANOVA analysis between dosage and embryo length on $23^{\text {rd }}$ day 


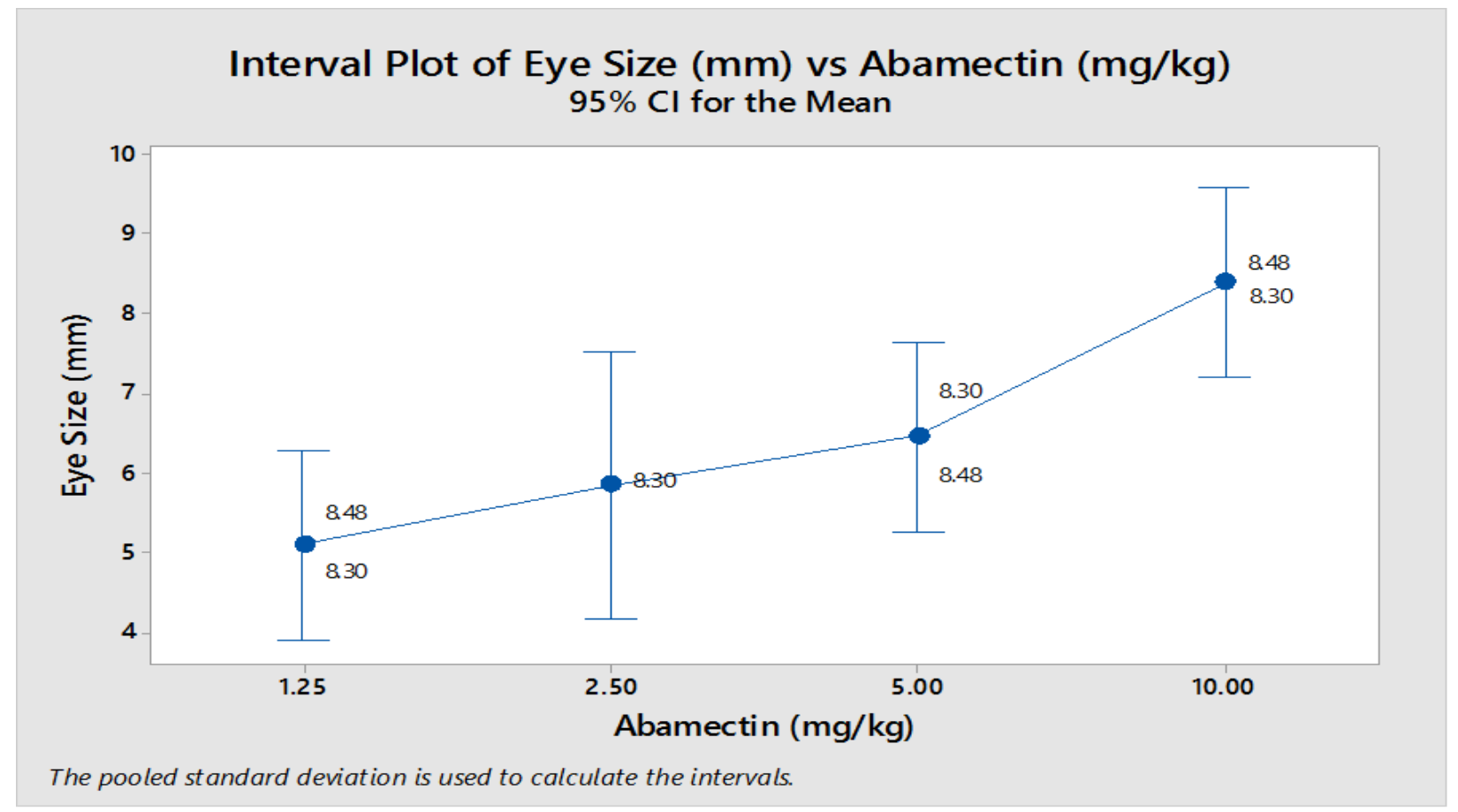

Graph 8. One-way ANOVA analysis between dosage and eye size of chicks on $23^{\text {rd }}$ day

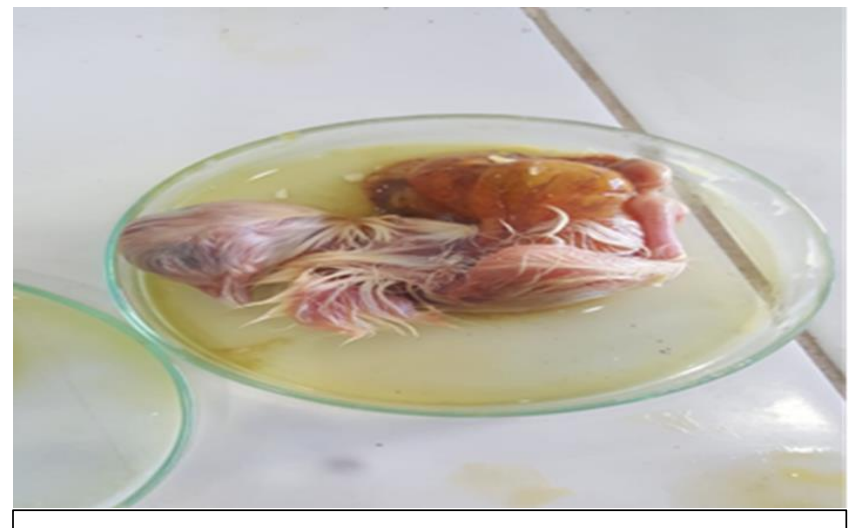

Figure 10. Failure of yolk sac retraction
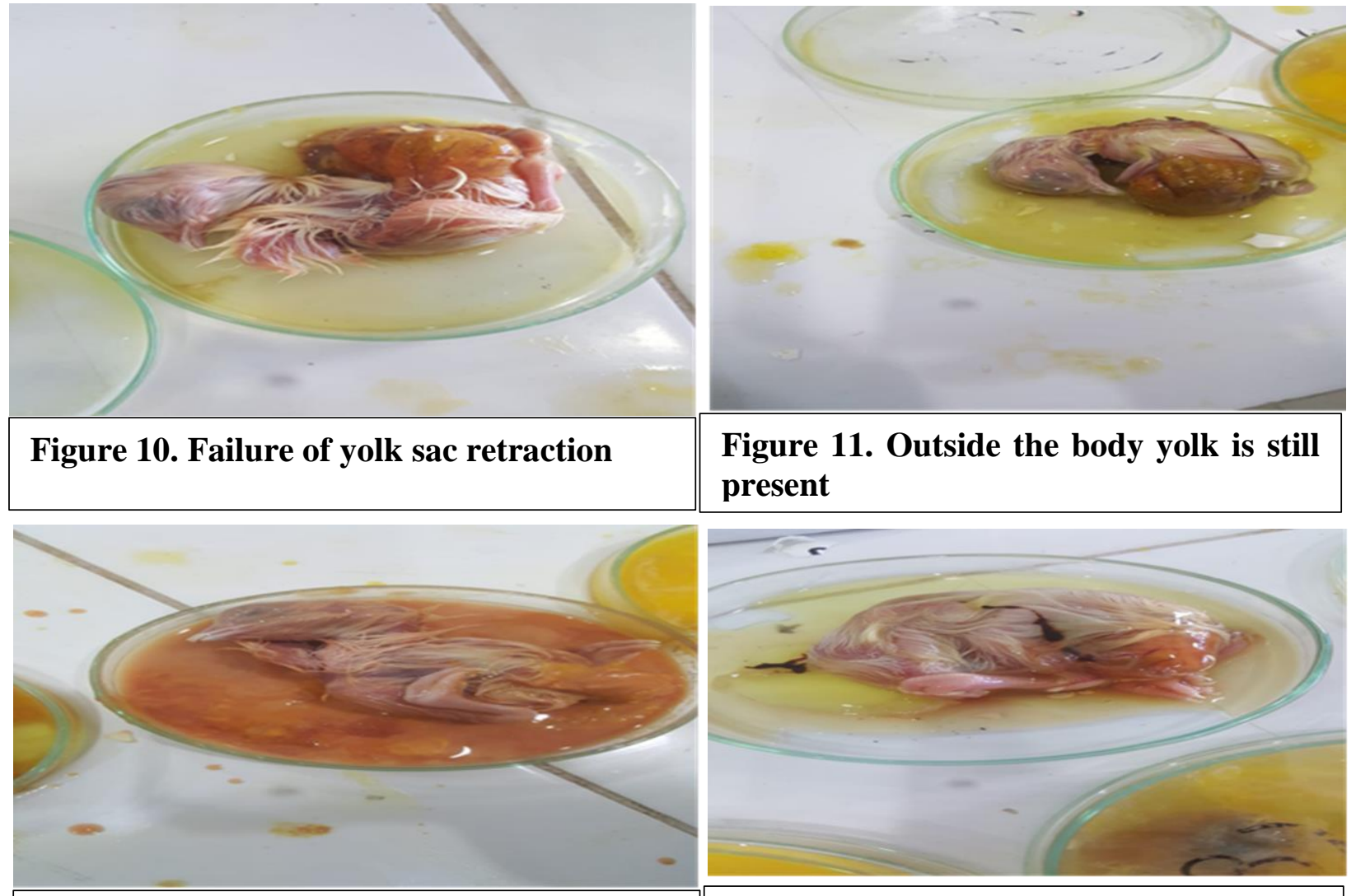

Figure 12. Ruptured yolk sac in exnerimental groun

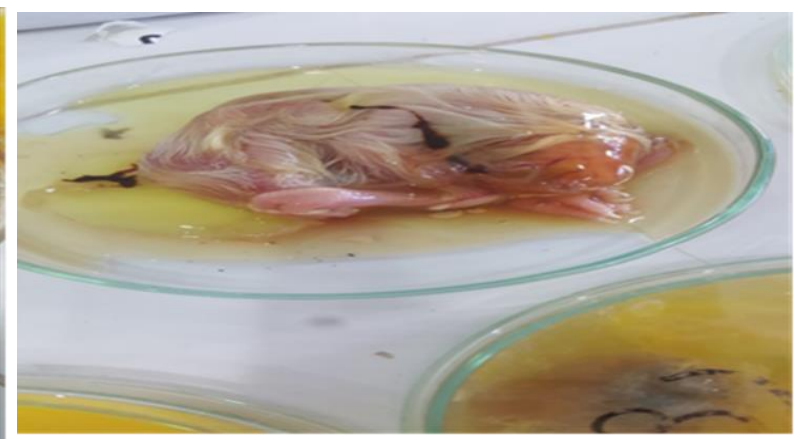

Figure 13. Ectopia viscera seen in chicks of experimental group 


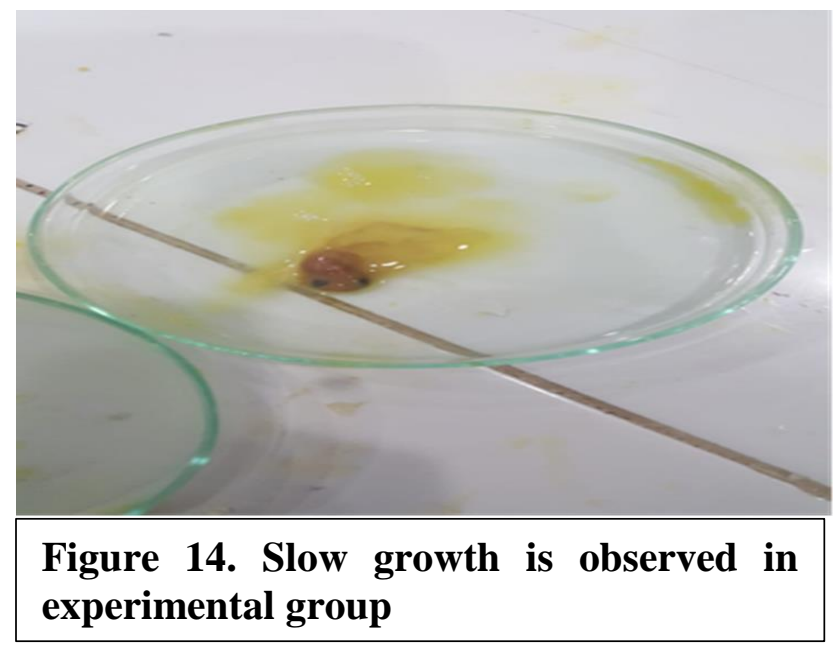

\section{Discussion}

Chicks are preferred as model organisms due to their genetic similarity and analogous homology of structure with humans also they have short development period so that results can be elaborated in short time [14, 15]. In recent years use of abamectin is increased besides of its multi benefits it also has some harmful impacts [16]. In many animals, Abamectin is found to have adverse effect [17]. Previous studies have proved the toxicological impact of abamectin on other animals but nothing is known about its teratogenic effect on chicks that's why we selected chick to observe the teratogenic effect of abamectin on them. In experiment of Abol-El-Saad and colleagues, On treatment with abamectin total count of RBCs was decreased while that of WBCs was nonsignificantly increased as compared to control ones in male albino rats [5]. In our study little adverse effects were observed in group B injected with $5 \mathrm{mg} / \mathrm{L}$ dose of abamectin like Blood vessels were damaged, heart was ruptured and further development of blood vessels were arrested. In our experiment, embryos treated with $1.25 \mathrm{mg} / \mathrm{L}$ show poor limb formation, poor development of blood vessels, heart, feather germ layer and small size of embryo, with decreasing drug doses, effects were more prominent. Further Celik-Ozenci observed that AVM

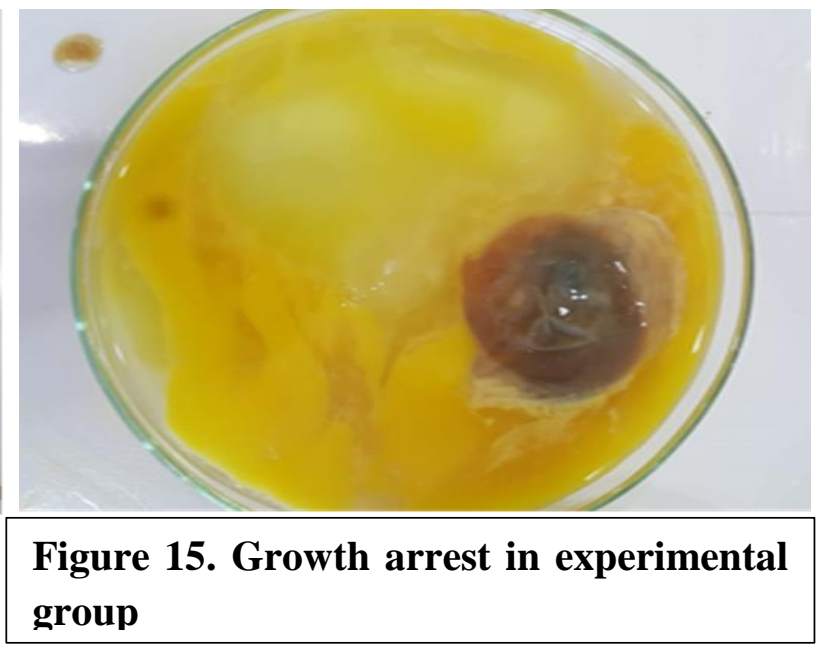

causes the inhibition of neuronal mitochondria activity, increase in activities of CASPASES-3 and 9 which indicates that AVM induces the apoptosis of the culture brain neurons through mitochondria injury [10]. In our study, embryos injected with increase in dose to $1.25 \mathrm{mg} / \mathrm{L}$ showed ectopia viscera, with small eyes and heart developed, without limbs formation. In group $\mathrm{C}$ injected with $2.5 \mathrm{mg} / \mathrm{Kg}$ of abamectin chicks shows delaying in hatching, failure of yolk sac retraction and has reduced body weight and embryo length.

In other research, after abamectin exposure, increase in chloride ions hyperpolarizes the nerve and muscle cells, ultimately interfering with neuromuscular transmission, leading to death [7]. In our experiment, embryos injected with $5 \mathrm{mg} / \mathrm{Kg}$ dose of abamectin showed slow growth, poor yolk retraction. while group A injected with $10 \mathrm{mg} / \mathrm{Kg}$ dose of abamectin showed similarities with normal chicks, many of them hatched on normal time and few eggs were assisted in hatching yet their development is near to complete with proper formationn so we can conclude that abamectin affects the development rate time of hatching of growing chick embryo.

\section{Conclusion}

Abamectin being used as pesticide over crops on broad level any type of mishandling can drag bad effects so it is prerequisite to 
educate farmers in regard to its safe use. From our study, it can be concluded that abamectin imparts teratogenic effect in chick embryos that's why its use should be limited. As results showed that chicks of experimental group had more cases of growth retardation, poor yolk sac retraction and defects in size of eye and limb as compared to control group. Comparatively low doses proved to be more toxic and imparts defects in development and teratogenic effects in embryo.

\section{Authors' contributions}

Conceived and designed the experiments: S Perveen, Performed the experiments: K Zaffar \& U Khalid, Analyzed the data: N Sattar, Contributed materials/ analysis/ tools: Z Mustabshira, Wrote the paper: K Sardar.

\section{References}

1. Burg RW, Miller BM, Baker EE, Birnbaum J, Currie SA, Hartman R \& Tunac JB (1979). Avermectins, new family of potent anthelmintic agents: producing organism and fermentation. Antimicrobial Agents and Chemothy 15(3): 361-367.

2. Putter I, Mac Connell JG, Preiser FA, Haidri AA, Ristich SS \& Dybas RA (1981). Avermectins: novel insecticides, acaricides and nematicides from a soil microorganism. Experientia 37(9): 963 964.

3. Novelli A, Vieira BH, Braun AS, Mendes LB, Daam MA \& Espíndola ELG (2016). Impact of runoff water from an experimental agricultural field applied with Vertimec ${ }^{\circledR} \quad 18 \mathrm{EC}$ (abamectin) on the survival, growth and gill morphology of zebrafish juveniles. Chemosphere 144: 1408-1414.

4. Halley BA, Vanden Heuvel WJ \& Wislocki PG (1993). Environmental effects of the usage of avermectins in livestock. Vet Parasitol 48(1-4): 109125.
5. Abo-El-Saad MM, Elshafie HA \& BouKhowh IA (2013). Toxicity of bioinsecticide, Abamectin, on red palm weevil, Rhynchophorus ferrugineus (Olivier). Int J Agric Sci Res 2: 107-115.

6. Sanches ALM, Vieira BH, Reghini MV, Moreira RA, Freitas EC, Espíndola EL $\&$ Daam MA (2017). Single and mixture toxicity of abamectin and difenoconazole to adult zebrafish (Danio rerio). Chemosphere 188: 582-587.

7. Campbell WC (1989). Use of ivermectin in dogs and cats. In Ivermectin and abamectin. Springer, New York, NY pp 245-259.

8. Isales GM, Hipszer RA, Raftery TD, Chen A, Stapleton HM \& Volz DC (2015). Triphenyl phosphate-induced developmental toxicity in zebrafish: potential role of the retinoic acid receptor. Aquatic Toxicol 161: 221-230.

9. Montalvão MF, de Souza JM, Guimarães ATB, de Menezes IPP, da Silva Castro AL, de Lima Rodrigues AS \& Malafaia $G$ (2017). The genotoxicity and cytotoxicity of tannery effluent in bullfrog (Lithobates catesbeianus). Chemosphere 183: 491-502.

10. Celik-Ozenci C, Tasatargil A, Tekcan M, Sati L, Gungor E, Isbir M \& Demir R (2011). Effects of abamectin exposure on male fertility in rats: potential role of oxidative stress-mediated poly (ADPribose) polymerase (PARP) activation. Regulatory Toxicol and Pharmacol 61(3): 310-317

11. de Faria DBG, Montalvão MF, de Souza JM, de Oliveira Mendes B, Malafaia G \& de Lima Rodrigues AS (2018). Analysis of various effects of abamectin on erythrocyte morphology in Japanese quails (Coturnix japonica). Environ Sci and Poll Res 25(3): 2450-2456.

12. Abongwa M, Martin RJ \& Robertson AP (2017). A brief review on the mode of 
action of antinematodal drugs. Acta Vet 67: 137152.

13. Cui YL, Wang M, Huang W, Guan LP \& Li S (2007). Avermectin-induced mitochondria damage and apoptosis in cultured pigeon neurons [J]. Vet Sci in China, pp 11.

14. Vargas A, Zeisser-Labouèbe M, Lange N, Gurny R \& Delie F (2007). The chick embryo and its chorioallantoic membrane (CAM) for the in vivo evaluation of drug delivery system. Adv drug Del Rev 59(11): 1162-1176.

15. Smith SM, Flentke GR \& Garic A (2012). Avian Models in Teratology and
Developmental Toxicology. In C Harris \& JM Hansen (Eds.), Developmental Toxicology: Methods and Protocols. Totowa, NJ: Humana Press, pp 85-103.

16. Sorensen PB, Giralt F, Rallo R, Espinosa G, Munier B, Gyldenkaerne S \& Thomsen MA (2010). Methodological cause study for pesticide risk assessment 408(18): 3860-3870.

17. Ministério da Agricultura, Pecuária e Abastecimento (MAPA) Brazil (2017). Consulta de ingredient ativo. Avaiable in: http://agrofit.agricultura.gov.br/agrofit_ cons/principal_agrofit_cons 